\title{
Permafrost degradation on a warmer Earth: Challenges and perspectives M. Oliva ${ }^{\mathrm{a}}$ and M. Fritz
}

\begin{abstract}
Permafrost, the permanently frozen ground, is warming due to global temperature rise. Permafrost research has progressed rapidly in the last decade, as large areas in the Polar Regions, in mountain environments and on high-altitude plateaus are experiencing accelerated environmental changes in response to thaw and permafrost degradation. Climate scenarios for the next decades project a reduced the extent of permafrost coverage and increasing ground temperatures, promoting changes in terrestrial and nearshore ecosystem dynamics. Future research in permafrost regions should focus on a better understanding of the biogeochemical cycles associated with abrupt and long-term permafrost degradation. Risk assessment of natural hazards and geoenvironmental engineering solutions are needed to reduce the potential dramatic socioeconomic implications that permafrost degradation may entail in these regions.

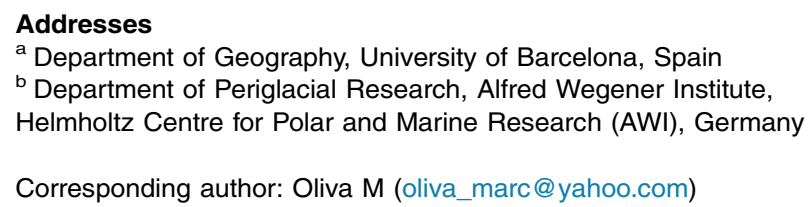

Current Opinion in Environmental Science \& Health 2018, 5:14-18

This review comes from a themed issue on Sustainable Soil Management

Edited by Paulo Pereira and Juan Martinez-Murillo

For a complete overview see the Issue and the Editorial

https://doi.org/10.1016/j.coesh.2018.03.007

2468-5844/( 2018 Elsevier B.V. All rights reserved.

\section{Keywords}

Permafrost, Frozen ground, Polar regions, Mountains, Climate.

\section{Introduction}

Permafrost - defined as the ground that remains below $0{ }^{\circ} \mathrm{C}$ for at least two consecutive years [1] - extends over a surface of $22 \pm 310^{6} \mathrm{~km}^{2}$, mostly in the northern hemisphere, and therefore constitutes one of the most widespread components of the cryosphere [2]. The current distribution of permafrost conditions includes high latitude regions, together with high mountain regions and high-altitude plateaus in mid- and lowlatitude environments [3]. However, geomorphic evidence of past permafrost conditions shows that the area affected by frozen ground during Quaternary cold stages, such as the Last Glaciation, was much larger than today $[4,5]$.

In this paper, we examine recent trends in permafrost research as well as the new challenges that the changing climate will pose to permafrost environments in the forthcoming decades.

\section{The last decade in permafrost research}

The 4th International Polar Year (IPY 2007-2008) favored a substantial increase in the number and in the multidisciplinary design of permafrost studies (Fig. 1). Due to the large extent occupied by permafrost in the high latitudes of the northern hemisphere and the need of Arctic states to manage risks and opportunities arising from environmental change in the northern circum-polar regions, Arctic permafrost is the best examined permafrost region, e.g. [6-8].

Recently, mountain permafrost and its degradation is becoming a key research topic as temperatures in highelevation environments are increasing more rapidly than in the lowlands [9] in parallel to increased tourism pressure in these areas, which might trigger catastrophic natural hazards associated with rockfall and mudflow, e.g. [10]. In Antarctica and on high altitude plateaus, significant advances have been achieved in research on the distribution and thermal properties of permafrost, e.g. [11-14].

Since the IPY, permafrost research has focused on several key topics:

(1) Mapping and modeling of permafrost distribution, e.g., $[2,15,16]$.

(2) Monitoring of thermal properties of the permafrost and active layer, e.g., [17-20].

(3) Geomorphological processes and natural hazards, e.g., $[10,21,22]$.

(4) Biogeochemical and ecological shifts driven by permafrost changes, e.g., [7,23-25].

(5) Geotechnical and engineering issues for hazard assessment and the construction of sustainable infrastructures in permafrost regions, e.g., [26-28].

(6) Geopolitical and management policies to mitigate some of these changes, e.g., [29,30].

Most of the studies highlight the sensitivity of permafrost environments to changing climate and land-use transformations, pointing out the need to better 


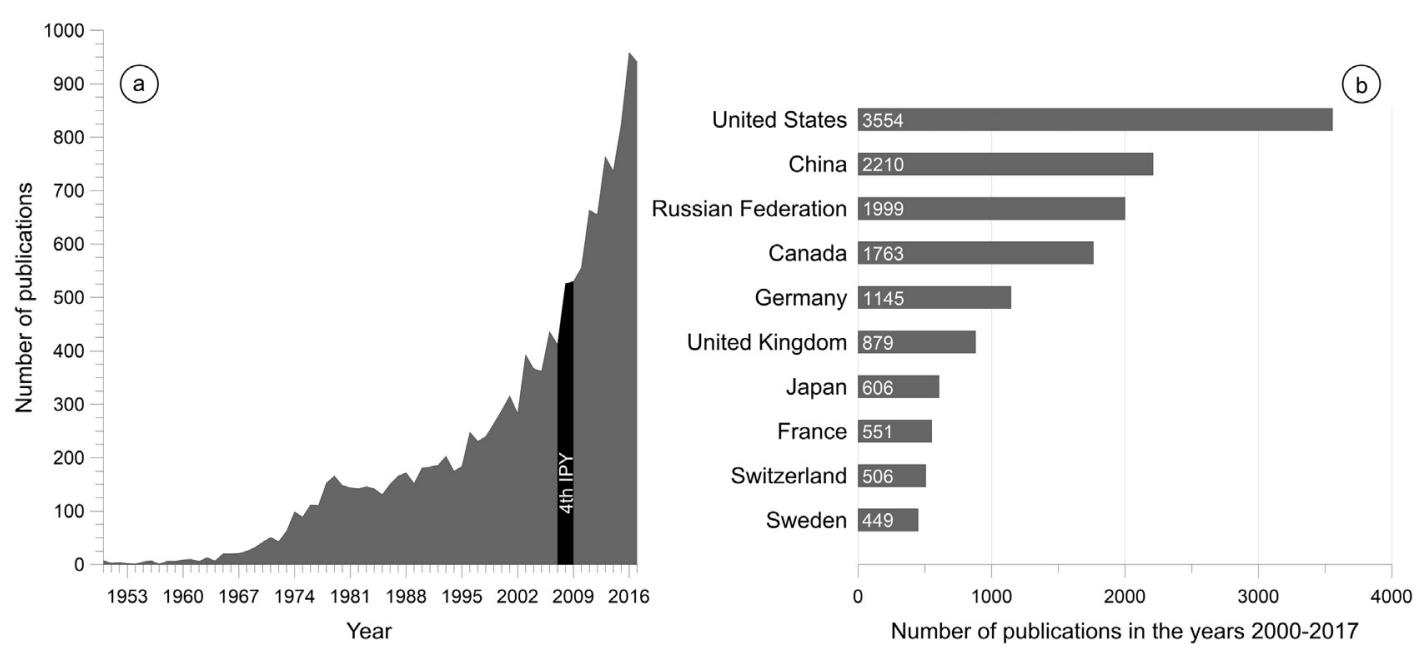

Permafrost publication statistic (a) from 1950 until 2017 and (b) permafrost-related publications between 2000 and 2017 by country. The query was done in Scopus using the keywords "permafrost" and/or "frozen ground" in articles and reviews as publication type. Query words were applied to the title, abstract and keywords of the publications.

understand its role as key component of the cryosphere as well as its interactions with other processes, namely the climate system.

\section{Challenges and perspectives}

The air temperature increase recorded over the last decades in permafrost regions is impacting permafrost temperatures, which are rising globally and favoring a deepening of the active layer. Since the International Polar Year (IPY) 2007-2008, the global mean permafrost temperature increased by $0.31 \pm 0.10{ }^{\circ} \mathrm{C}$ per decade, with an increase of $0.46 \pm 0.15^{\circ} \mathrm{C}$ in the continuous permafrost zone near the depth of zero annual amplitude, $0.21 \pm 0.09{ }^{\circ} \mathrm{C}$ in the discontinuous permafrost, $0.19 \pm 0.05{ }^{\circ} \mathrm{C}$ in mountain permafrost and $0.37 \pm 0.10^{\circ} \mathrm{C}$ in Antarctic permafrost [31]. This has major implications for geomorphological, hydrological and biological processes in permafrost regions [6,32], but it may also have large consequences for climate at global scale through permafrost thawing in the Arctic and associated feedback processes $[33,34]$.

The continuation (and possible acceleration) of this warming trend recorded over the last decades may imply a significant reduction in the surface underlain by the permanently frozen ground [35]. Some permafrost regions are predicted by climate models to warm more intensely over the next decades. Consequently, the scientific community needs to generate more data to better understand the negative and possibly catastrophic effects this warming trend may have for the whole climate system, in order to anticipate and mitigate its consequences as much as possible. Depending on the rates of warming, the area occupied by permafrost near the surface ( $3.5 \mathrm{~m}$ depth) might be reduced by between $37 \%$ and $81 \%$, and thus retreats to higher latitudes and higher elevations are expected [36]. Consequently, most high latitude environments conditioned nowadays by the presence of permafrost will be affected by the changing climate that will make it disappear or lead to a deepening of the active layer along with higher subsurface temperatures [37].

Permafrost thawing, particularly in regions where ground temperatures are close to $0^{\circ} \mathrm{C}$, may have implications on biogeochemical fluxes and affect the carbon cycle and greenhouse gas fixation, namely $\mathrm{CO}_{2}, \mathrm{CH}_{4}$ and $\mathrm{N}_{2} \mathrm{O}$, e.g., $[34,38-40]$. Turning permafrost from a greenhouse gas sink into a source, these positive feedbacks may accelerate in the future and therefore reinforce the degree of future global warming already anticipated by international reports [36]. However, there are still large discrepancies about the rate and magnitude of the contribution of thawing permafrost to greenhouse gas emissions, which may condition smoothed, progressive or threshold-type environmental and climatic responses.

In many areas, particularly in some highly populated Arctic regions, socioeconomic activities are already affected by permafrost thawing and degradation. Ground instability is impacting the dense network of equipment and infrastructures existing in these regions $[22,41,42]$. With the warming climate anticipated during the next decades, it is expected that permafrost degradation will increase in these regions and therefore local, regional and national administrations will have to invest large sums to adapt the infrastructures to the changing landscape $[37,42,43]$. Implementing an 
integrated approach combining scientific knowledge on permafrost dynamics and engineering advances is crucial to manage strategies to balance the construction of infrastructures and human development in a changing climate and provide geosystem and ecosystem services [8].

Apart from the impact on human livelihood, permafrost degradation is also expected to accelerate the effects on the natural dynamics of terrestrial ecosystems, by affecting geomorphic processes, hydrological dynamics of rivers, ponds and lakes as well as altering biodiversity in many areas. There is increased evidence that marine ecosystems will be also affected by the degradation of both terrestrial and subsea permafrost [44] as well as permafrost collapse in Arctic coastal environments [7]. Consequently, there is increased need to combine microscale experiments and large-scale remote sensing activities in order to better understand the interactions of the different land systems in changing permafrost landscapes at multiple scales.

Permafrost thaw will also affect biological dynamics in a wide range of processes; some of them are still poorly understood. There is increasing evidence of the complex diversity and functionality of the permafrost microbiome, and the impacts that thaw may have on greenhouse-gas emissions in response to accelerated microbial turnover [45]. Furthermore, a deepening of the active layer will also increase the risks of the emergence of zoonotic infectious diseases [46] or even the release of pathogenic DNA viruses stored in the permafrost [47]. Consequently, permafrost scientists need to examine the impacts of potential infectious diseases spreading across the Arctic in a warming climate and also to raise awareness of the threats that this trend may pose to local communities [46].

\section{Conclusions}

We conclude that permafrost research must be also seen as an opportunity to bridge the gap between science and society. The media response about permafrost degradation has drastically increased in recent years and contributes to raise awareness of the challenges related to a regional phenomenon of global importance. The threats posed by permafrost degradation in northern societies have become a central research focus in the scientific community, so that involving local and traditional knowledge via research co-design and stakeholder consultation is becoming a new paradigm in permafrost science. Beyond scientific literature products, education and outreach activities should not be underestimated to communicate our findings into society and to reach out for feedback [48]. Ultimately, a better understanding of permafrost evolution in a changing climate is of utmost importance, both from a local and global perspective.

\section{Acknowledgments}

Marc Oliva is supported by the Ramón y Cajal Program and the PALEOGREEN project (CTM2017-87976-P), both funded by the Spanish Ministry of Economy and Competitiveness (RYC-2015-17597), as well as by the research group ANTALP (Antarctic, Arctic and Alpine environments). The work of Michael Fritz is supported by the Daimler and Benz Foundation (grant number 32-02/15). This project has received funding from the European Union's Horizon 2020 research and innovation programme under grant agreement number 773421 (NUNATARYUK).

\section{References}

Papers of particular interest, published within the period of review, have been highlighted as:

* of special interest

** of outstanding interest

1. French HM: The periglacial environment. 3rd ed. John Wiley; 2007.

2. Gruber S: Derivation and analysis of a high-resolution estimate of global permafrost zonation. Cryosphere 2012, 6: 221-233.

3. Brown J, Ferrians OJ, Heginbottom JA, Melnikov ES. Circumarctic map of permafrost and ground ice conditions. Circumpacific map series. Edited by the US Geological Survey; 2001.

4. Vandenberghe J, French HM, Gorbunov A, Velichko AA, Jin $H$, Cui Z, Zhang T, Wan X: The Last Permafrost Maximum (LPM) map of the northern hemisphere: permafrost extent and mean annual air temperatures, 25-17 ka BP. Boreas 2014, 43: $652-666$.

5. Kitover DC, van Balen RT, Vandenberghe J, Roche DM, Renssen H: LGM permafrost thickness and extent in the northern hemisphere derived from the Earth system model iLOVECLIM. Permafr Periglac Process 2016, 27:31-42.

6. Rowland JC, Jones CE, Altmann G, Bryan R, Crosby BT, Hinzman LD, Kane DL, Lawrence DM, Mancino A, Marsh P, McNamara JP, Romanvosky VE, Toniolo H, Travis BJ, Trochim E, Wilson CJ, Geernaert GL: Arctic landscapes in transition: responses to thawing permafrost. EOS Trans Am Geophys Union 2010, 91:229-230.

7. Fritz M, Vonk JE, Lantuit $\mathrm{H}$ : Collapsing arctic coastlines. Nat ** Clim Change 2017, 7:6-7.

The authors demonstrate that the Arctic nearshore zone along permafrost coasts is systematically understudied. They highlight the drastic impacts of climate change in the Arctic land-ocean continuum on global carbon fluxes and their climate feedbacks, on nearshore food webs, and on local communities.

8. Vincent WF, Lemay M, Allard M: Arctic permafrost landscapes in transition: towards an integrated Earth system approach. Arct Sci 2017, 3:39-64.

This review calls for an Earth system approach in permafrost research to provide a framework for identifying linkages, thresholds, and feedbacks among system components. One major focus is laid on considering the human systems and to strengthen the development of management strategies to cope with permafrost change.

9. Pepin N, Bradley RS, Diaz HF, Baraer M, Caceres EB, ** Forsythe N, Fowler H, Greenwood G, Hashmi MZ, Liu XD, Miller JR, Ning L, Ohmura A, Palazzi E, Rangwala I, Schöner W, Severskiy I, Shahgedanova M, Wang MB, Williamson SN,

Yang DQ: Elevation-dependent warming in mountain regions of the world. Nat Clim Change 2015, 5:424-430.

This study calls for special attention to elevation-dependent warming because warming is amplified with elevation, so that high-mountain environments experience more rapid changes in temperature than environments at lower elevations. The authors review mechanisms that all lead to enhanced warming with elevation, which are snow albedo feedbacks; water vapour changes and latent heat release; surface water vapour and radiative flux changes; surface heat loss and temperature change; and aerosols.

10. Ravanel L, Magnin F, Deline P: Impacts of the 2003 and 2015 summer heatwaves on permafrost-affected rock-walls in the Mont Blanc massif. Sci Total Environ 2017, 609:132-143. 
11. Vieira G, Bockheim J, Guglielmin M, Balks M, Abramov AA, Boelhouwers J, Cannone N, Ganzert L, Gilichinsky D, Goryachkin S, López-Martínez J, Raffi R, Ramos M, Schaefer C, Serrano E, Simas F, Sletten R, Wagner D: Thermal state of permafrost and active-layer monitoring in the Antarctic: advances during the International Polar Year 2007-2008. Permafi Periglac Process 2010, 21:182-197.

12. Bockheim JG, Vieira G, Ramos M, López-Martínez J, Serrano E, Guglielmin M, Wilhelm K, Nieuwendam A: Climate warming and permafrost dynamics in the Antarctic Peninsula region. Global Planet Change 2013, 100:215-223.

13. Oliva M, Ruiz-Fernández J: Coupling patterns between paraglacial and permafrost degradation responses in Antarctica. Earth Surf Process Landforms 2015, 40:1227-1238.

14. Lu Q, Zhao D, Wu S: Simulated responses of permafrost distribution to climate change on the Qinghai-Tibet Plateau. Sci Rep 2018, 7:3845.

A Surface Frost Number model was applied under the different RCP scenarios for simulating the permafrost distribution on the Qinghai-Tibet Plateau, which is the largest permafrost area outside of the polar regions and water source for more than a billion people. Simulated results suggest a decrease in permafrost distribution of up to $64.3 \%$ until the end of the century.

15. Boeckli L, Brenning A, Gruber S, Noetzli J: A statistical approach to modelling permafrost distribution in the European Alps or similar mountain ranges. Cryosphere 2012, 6: $125-140$.

16. Azócar GF, Brenning A, Bodin X: Permafrost distribution modelling in the semi-arid Chilean Andes. Cryosphere 2017, 11:877-890.

17. Lewkowicz A: The lasting impacts of the fourth international polar year on permafrost science. Permafr Periglac Process 2010, 21:105.

18. Romanovsky VE, Smith SL, Christiansen $\mathrm{HH}$ : Permafrost thermal state in the polar Northern Hemisphere during the international polar year 2007-2009: a synthesis. Permafr Periglac Process 2010, 21:106-116.

19. Biskaborn BK, Lanckman JP, Lantuit H, Elger K, Streletskiy DA, Cable WL, Romanovsky VE: The new database of the global terrestrial network for permafrost (GTN-P). Earth Syst Sci Data 2015, 7:245-259.

20. Oliva M, Pereira P, Ruiz-Fernández J, Nieuwendam A: Recent advances in the study of active layer thermal regime and seasonal frost dynamics in cold climate environments. Catena 2017, 149:515-518.

21. Kääb A, Reynolds JM, Haeberli W: Glacier and permafrost hazards in high mountains. In Global change and mountain regions. Advances in global change research. Edited by Huber UM, Bugmann HKM, Reasoner MA, Springer; 2005: 225-234.

22. Melvin AM, Larsen $P$, Boehlert B, Neumann J, Chinowsky $P$ Espinet X, Martinich J, Baumann MS, Rennels L, Bothner A, Nicolsky D, Marchenko S: Climate change damages to Alaska public infrastructure and the economics of proactive adaptation. Proc Natl Acad Sci India A 2017, 114:122-131.

This study quantified the economic impacts of climate change on Alaskan public infrastructure under RCP8.5 and RCP4.5 and calls for proactive adaptation to reduce mitigation costs. Cumulative estimated expenses from climate-related damage to infrastructure without adaptation measures from 2015 to 2099 totaled 5.5 billion US-Dollars for RCP8.5 and $\$ 4.2$ billion for RCP4.5.

23. Yang Z, Hua Ou Y, Xu X, Zhao L, Song M, Zhou C: Effects of permafrost degradation on ecosystems. Acta Ecol Sin 2010, 30:33-39.

24. Vonk JE, Tank SE, Bowden WB, Laurion I, Vincent WF, Alekseychik P, Amyot M, Billet MF, Canário J, Cory RM', Deshpande BN, Helbig M, Jammet M, Karlsson J, Larouche J, MacMillan G, Rautio M, Walter-Anthony KM, Wickland KP: Effects of permafrost thaw on Arctic aquatic ecosystems. Biogeosciences 2015, 12:7129-7167.

A review about the magnitude of thaw impacts on northern aquatic ecosystems. The authors show how the biogeochemistry and ecology of thaw-impacted lakes and streams in northern permafrost regions is likely to change with regard to carbon balance, microbiological communities, primary production, and food web structure.

25. Zona D: Biogeochemistry: long-term effects of permafrost thaw. Nature 2017, 537:625-626.

26. Harris C, Arenson LU, Christiansen $\mathrm{HH}$, Etzelmüller B, Frauenfelder R, Gruber S, Haeberli W, Hauck C, Hölzle M, Humlum $\mathrm{O}$, Isaksen $\mathrm{K}$, Kääb $\mathrm{A}$, Kern-Lütschg MA, Lehning M, Matsuoka N, Murton JB, Noetzli J, Phillips M, Ross N, Seppälä M, Springman SM, Vonder Mühll D: Permafrost and climate in Europe: monitoring and modelling thermal, geomorphological and geotechnical responses. Earth Sci Rev 2009, 92: $117-171$.

27. Bommer C, Phillips M, Arenson LU: Practical recommendations for planning, constructing and maintaining infrastructure in mountain permafrost. Permafr Periglac Process 2010, 21: 97-104.

28. Krautblatter M, Huggel C, Deline P, Hasler A: Why permafrost rocks become unstable: a rock-ice-mechanical model in time and space. Earth Surf Proc Land 2012, 38:876-887.

29. Østerud Ø, Hønneland G: Geopolitics and international governance in the Arctic. Arct Rev Law Polit 2014, 5:156-176.

30. Fritz M, Deshpande BN, Bouchard F, Högström E, Lepage J, Morgenstern A, Nieuwendam A, Oliva M, Paquette M, Rudy AC, Siewert MB, Sjöberg Y, Weege S: Future avenues for permafrost science from the perspective of early career researchers. Cryosphere 2015, 9:1715-1720.

31. Biskaborn BK, Smith SL, Noetzli J, Vieira G, Streletskiy D, Schoeneich P, Romanovsky V, Wu Q, Christiansen H, Lanckman JP, Abramov A, Allard M, Boike J, Delaloye R, Derevyanko I, Diekmann B, Drozdov D, Etzelmüller B, Grosse G, Guglielmin M, Ingeman-Nielsen T, Isaksen K, Ishikava M, Johannson M, Johannsson H, Joo A, Kholodov A, Konstantinov P, Kröger T, Lambiel C, Lewkovicz A, Luo D, Malkova G, Matthes H, Meiklejohn I, Moskalenko N, Kaverin D, Oliva M, Paetzold R, Phillips M, Ramos M, Sannel B, Sergueev D, Seybold C, Skryabin P, Sletten R, Yoshikawa K, Zheleznyak M, Lantuit H: Global permafrost temperatures on the rise. Nat Commun 2018. submitted.

32. Oliva M, Pereira P, Antoniades D: The environmental consequences of permafrost degradation in a changing climate. $\mathrm{Sci}$ Total Environ 2017, 616-617:435-437.

33. Schaefer K, Lantuit H, Romanovsky VE, Schuur EA, Witt R: The impact of the permafrost carbon feedback on global climate. Environ Res Lett 2014, 9, https://doi.org/10.1088/1748-9326/9/8/ 085003.

34. Schuur EAG, McGuire AD, Schädel C, Grosse G, Harden JW, Hayes DJ, Hugelius G, Koven CD, Kuhry P, Lawrence DM, Natali SM, Olefeldt D, Romanovsky VE, Schaefer K, Turetsky MR, Treat CC, Vonk JE: Climate change and the permafrost carbon feedback. Nature 2015, 520:171-179.

35. Slater AG, Lawrence DM: Diagnosing present and future permafrost from climate models. J Climate 2013, 26: $5608-5623$.

36. IPCC Climate Change: The physical science basis. Contribution of working group I to the fifth assessment report of the intergovernmental panel on climate change. Cambridge University Press; 2013.

37. AMAP: Snow, water, ice and permafrost. Summary for policymakers. Arctic Monitoring and Assessment Programme; 2017.

Dedicated to a non-scientific audience this report summarizes key findings and implications of thawing permafrost to global climate, ecology, human health, and northern communities.

38. Hugelius G, Strauss J, Zubrzycki S, Harden JW, Schuur EAG, Ping CL, Schirrmeister L, Grosse G, Michaelson GJ, Koven CD, O'Donnell JA, Elberling B, Mishra U, Camill P, Yu Z, Palmtag J, Kuhry P: Estimated stocks of circumpolar permafrost carbon with quantified uncertainty ranges and identified data gaps. Biogeosciences 2014, 11:6573-6593.

39. Zubrzycki S, Kutzbach L, Pfeiffer EM: Permafrost-affected soils and their carbon pools with a focus on the Russian Arctic. Solid Earth 2014, 5:595-609. 
40. Voigt C, Marushchak ME, Lamprecht RE, JackowiczKorczynski M, Lindgren A, Mastepanov M, Granlund L, Christensen TR, Tahvanainen T, Martikainen PJ, Biasi C: Increased nitrous oxide emissions from Arctic peatlands after permafrost thaw. Proc Natl Acad Sci India A 2017, 114: 6238-6243.

41. Guo D, Sun J: Permafrost thaw and associated settlement hazard onset timing over the Qinghai-Tibet engineering corridor. Int J Disast Risk Sci 2015, 6:347-358.

42. UNEP report Schaefer $K$, Lantuit $H$, Romanovsky V, Schuur E: Policy implications of warming permafrost. United Nations Environment Programme. 2012.

43. Hope C, Schaefer K: Economic impacts of carbon dioxide and methane released from thawing permafrost. Nat Clim Change 2015, 6:56-69.

44. Shakhova N, Semiletov I, Gustafsson O, Sergienko V, Lobkovsky L, Dudarev O, Tumskoy V, Grigoriev M, Mazurov A, Salyuk A, Ananiev R, Koshurnikov A, Kosmach D, Charkin A, Dmitrevsky N, Karnaukh V, Gunar A, Meluzov A, Chernykh D: Current rates and mechanisms of subsea permafrost degradation in the East Siberian Arctic Shelf. Nat Commun 2017, 8:15872.

Quantifies rates of subsea permafrost degradation and occurrence of gas-migration pathways as key factors for methane $(\mathrm{CH} 4)$ emissions from a largely unknown but potentially huge carbon pool.

45. Jansson JK, Taş N: The microbial ecology of permafrost. Nat Rev Microbiol 2015, 12:414-425.

46. Revich B, Tokarevich N, Parkinson AJ: Climate change and zoonotic infections in the Russian Arctic. Int J Circumpolar Health 2012, 71:18792.

47. Legendre M, Bartoli J, Shmakova L, Jeudy S, Labadie K, Adrait A Lescot M, Poirot O, Bertaux L, Bruley C, Couté Y, Rivkina E, Abergel C, Claverie JM: Thirty-thousand-year-old distant relative of giant icosahedral DNA viruses with a pandoravirus morphology. Proc Natl Acad Sci India A 2014, 111:4274-4279.

48. Bouchard F, Sansoulet J, Fritz M, Paquette M, Ashley R, Siewert MB, Sjöberg Y, Tanski G, Harbor J: Frozen-Ground Cartoons: permafrost comics as a powerful tool for polar outreach, education, and engagement. 2018. to be submitted to Polar Rec. 